ORIGINAL ARTICLE

\title{
A Retrospective Analysis of Patients Presenting with Head and Neck Paragangliomas at Two Tertiary Referral Centres in Jamaica
}

P Brown ${ }^{1}$, A Batchelor ${ }^{2}$, H Ashman ${ }^{3}$, G Channer ${ }^{1}$

\begin{abstract}
Objective: Paragangliomas are slow-growing tumours that present with varied clinical spectra. Early recognition is paramount in achieving reduced morbidity and mortality. There is a paucity of data regarding head and neck paragangliomas (HNPGs) in the Caribbean literature. This study aimed to reflect the clinical experience in the management of HNPGs at two Jamaican tertiary referral centres: the Kingston Public Hospital (KPH) and the University Hospital of the West Indies (UHWI).

Methods: A retrospective analysis was conducted on all patients presenting to the Ear, Nose and Throat (ENT) departments of the UHWI in 2004-14 and of the KPH in 2012-14 with the diagnosis of a $H N P G$.

Results: There were 15 patients, 1 male and 14 females. The average age at presentation was 47.1 years. The HNPGs in this series included eight patients with glomus tympanicum (GT, $53 \%)$, four with glomus jugulare (GJ, 27\%), two with carotid body tumours (CBTs, 13\%) and one with glomus vagale (GV, 7\%). Eight patients underwent surgical resection (two CBTs, four GT and two GJ). Treatment outcomes achieved included: complete resection (four patients), stable with residual disease (two patients), and recurrence (two patients). Seven patients were awaiting definitive treatment, one patient with GJ was referred overseas, and one patient with GV defaulted.

Conclusion: Glomus tympanicum is the most common HNPG in this series which contrasts with that of most international series. Despite the limitations within this region, such as limited access to angio-embolization and stereotactic modalities, the management outcomes are similar in some respects to the reported international literature.
\end{abstract}

Keywords: Carotid body tumours, Fisch approach, glomus, paragangliomas

From: 'Ear, Nose and Throat division, Department of Surgery, Kingston Public Hospital, Kingston, Jamaica, West Indies, ${ }^{2}$ Department of Obstetrics and Gynaecology, University Hospital of the West Indies, Kingston, Jamaica, West Indies and ${ }^{3}$ Ear, Nose and Throat division, Department of Surgery, University Hospital of the West Indies, Kingston, Jamaica, West Indies.
Correspondence: Dr P Brown, Ear, Nose and Throat division, Department of Surgery, Kingston Public Hospital, North Street, Kingston, Jamaica, West Indies. Email: drphillipbrown.ent@gmail. com 


\title{
Análisis retrospectivo de pacientes que presentan paragangliomas de cabeza y cuello en dos centros de remisión terciarios en Jamaica
}

\author{
P Brown ${ }^{1}$, A Batchelor ${ }^{2}$, H Ashman $^{3}$, G Channer ${ }^{1}$
}

\begin{abstract}
RESUMEN
Objetivo: Los paragangliomas son tumores de crecimiento lento que se presentan con variados espectros clínicos. Su detección precoz es fundamental para lograr una reducción de la morbilidad y la mortalidad. Hay escasez de datos con respecto a los paragangliomas de cabeza y cuello (PgCC) en la literatura del Caribe. Este estudio tuvo como objetivo reflejar la experiencia clínica en el tratamiento de PgCC en dos centros de remisión terciarios de Jamaica: jamaiquinos: el Hospital Público de Kingston (KPH) y el Hospital Universitario de UWI (HUWI).

Métodos: Se llevó a cabo un análisis retrospectivo de todos los pacientes diagnosticados con PgCC que acudieron a los Departamentos de Otorrinolaringología de HUWI en 2004-14 y de KPH en 2012-14.

Resultados: Hubo 15 pacientes - 1 varón y 14 hembras. La edad promedio al momento de presentarse fue 47.1 años. El PgCC en esta serie incluyó a ocho pacientes con glomus timpánico (GT, 53\%), cuatro con glomus yugular (GY, 27\%), dos con tumores del cuerpo carotídeo (TCC, $13 \%)$, y uno con glomus vagal (GV, 7\%). Ocho pacientes fueron sometidos a resección quirúrgica (dos TCC, cuatro GT, y dos GY). Los resultados logrados con el tratamiento incluyeron: resección total (cuatro pacientes), estables con enfermedad residual (dos pacientes), y recurrencia (dos pacientes). Siete pacientes esperaban un tratamiento definitivo, un paciente con $G Y$ fue remitido al extranjero, y un paciente con $G V$ no se presentó.

Conclusión: El glomus timpánico es el PgCC más común en esta serie que contrasta con el de la mayoría de las series internacionales. A pesar de las limitaciones dentro de esta región, tales como el acceso limitado a la angioembolización y las modalidades estereotácticas, los resultados del manejo de la enfermedad son similares en algunos aspectos a la literatura internacional reportada.
\end{abstract}

Palabras clave: Tumores del cuerpo carotídeo, enfoque Fisch, glomus, paragangliomas

West Indian Med J 2018; 67 (1): 26

\section{INTRODUCTION}

Head and neck paragangliomas (HNPGs) are rare, slowgrowing, benign vascular tumours of paraganglionic tissue (1), accounting for $0.6 \%$ of all head and neck tumours (2). The estimated incidence is 1 in 30000 (3). Head and neck paragangliomas are classified regionally as cervical that include carotid body tumours (CBTs)/ glomus vagale $(\mathrm{GV})$ and temporal that include glomus tympanicum (GT)/glomus jugulare (GJ) tumours.

Diagnosis is predicated on clinical evaluation and specific imaging characteristics. Biopsy is usually not advocated due to their vascularity. The treatment modalities employed include surgical and non-surgical approaches (observation, stereotactic modalities and conventional radiotherapy), depending on patient, pathological features, surgeon and institutional factors.

This retrospective study, first of its kind in Jamaica and with the largest series to date within the Caribbean, aimed to reflect the clinical experience of two tertiary referral centres in the management of HNPGs with a comparison with the international reported literature.

\section{SUBJECTS AND METHODS}

A retrospective analysis was conducted on all patients presenting with the diagnosis of a HNPG to the Ear, Nose and Throat (ENT) departments of the University Hospital of the West Indies (UHWI) in 2004-14 and of the Kingston Public Hospital (KPH) in 2012-14. The 
data collated included demographics, clinical features, investigations and treatment outcomes. The ethics committees of the UHWI and KPH approved the study.

\section{RESULTS}

\section{Demographics}

The average age at presentation was 47.1 years, with an age range of 13 to 71 years. The male to female ratio was $1: 14$. The only male patient had GV. The majority of the patients, $73 \%(11 / 15)$, presented between the fourth and sixth decades of age.

\section{Clinical features}

The clinical features of the patient cohort are summarized in Table 1. All patients with cervical HNPGs (CBTs and GV) presented with a lateral pulsatile neck mass and neck mass with oropharyngeal extension, respectively. The most common symptoms of temporal HNPGs were pulsatile tinnitus (87.5-100\%) and hearing loss (100\%). For GT tumours, the other symptoms in decreasing frequency were aural fullness $(37.5 \%)$, bloody otorrhoea $(25 \%)$ and vertigo (25\%). In contrast, for GJ lesions, the symptoms in decreasing frequency were vertigo $(75 \%)$ and bloody otorrhoea (50\%). The most common sign for temporal PGs was a vascular middle ear mass (100\%). Facial nerve palsy occurred in $25 \%$ of cases of both GT and GJ tumours. Lower cranial nerve $(\mathrm{CN})$ palsies occurred in two patients with GJ. No patient had multiple PGs, malignancy or evidence of a functional tumour.

\section{Investigations}

All patients had high-resolution computed tomography/computed tomography angiography and magnetic resonance imaging/magnetic resonance angiogram. The HNPGs (CBTs, GT, GJ, GV) were staged using Shamblin classification (4), Glasscock-Jackson classification
(5), Fisch classification (3) and University of Zurich classification (6), respectively. Vanillylmandelic acid tests were done in all patients and were within normal limits. Preoperative embolization was not employed as this modality was not available in the public sector in Jamaica.

\section{Treatment and outcomes}

Surgical outcomes are summarized in Table 2. Primary surgery alone was employed in seven patients and surgery/adjuvant radiotherapy in one patient. Both patients with CBTs were treated via a transcervical approach with no postoperative sequelae or recurrence after five to six years (Figure). Three patients with GT tumours had surgery via a postaural tympanomastoidectomy. Two of these patients (Cases 3 and 4) were asymptomatic 15 and 24 months postoperatively. Case 3 had residual disease left in the region of the sinus tympani

Table 1: Salient clinical features

\begin{tabular}{lcccc}
\hline Clinical features & $\begin{array}{c}\text { GT } \\
\mathbf{n = 8}\end{array}$ & $\begin{array}{c}\text { GJ } \\
\mathbf{n}=\mathbf{4}\end{array}$ & $\begin{array}{c}\text { CBT } \\
\mathbf{n = 2}\end{array}$ & $\begin{array}{c}\text { GV } \\
\mathbf{n}=\mathbf{1}\end{array}$ \\
\hline Pulsatile tinnitus & $7(87.5 \%)$ & $4(100 \%)$ & - & - \\
Hearing loss & $8(100 \%)$ & $4(100 \%)$ & - & - \\
Bloody/purulent otorrhoea & $2(25 \%)$ & $2(50 \%)$ & - & - \\
Aural fullness & $3(37.5 \%)$ & - & - & - \\
Vertigo & $2(25 \%)$ & $3(75 \%)$ & - & - \\
Aural polyp & $2(25 \%)$ & $1(25 \%)$ & - & - \\
Cranial nerve 7 palsy & $2(25 \%)$ & $1(25 \%)$ & - & - \\
Cranial nerve 9-12 palsies & - & $2(50 \%)$ & - & - \\
Vascular middle ear mass & $8(100 \%)$ & $4(100 \%)$ & - & - \\
Lateral pulsatile neck mass & - & - & $2(100 \%)$ & - \\
Oropharyngeal/lateral neck & - & - & - & $1(100 \%)$ \\
mass & & & & \\
\hline
\end{tabular}

GT - glomus tympanicum, GJ - glomus jugulare, CBT - carotid body tumour, $\mathrm{GV}$ - glomus vagale.

Table 2: Surgical outcomes

\begin{tabular}{lcllr}
\hline Case & Tumour/stage & Treatment & Outcomes & Follow-up (years) \\
\hline 1 & $\mathrm{CBT} / 2$ & transcervical incision & no complications/NED & 6 \\
2 & $\mathrm{CBT} / 2$ & transcervical incision & no complications/NED & 5 \\
3 & $\mathrm{GT} / 3$ & tympanomastoidectomy & stable with residual disease & 1.25 \\
4 & $\mathrm{GT} / 4$ & tympanomastoidectomy & no complications/NED & 2 \\
5 & $\mathrm{GT} / 4$ & tympanomastoidectomy & local recurrence/SWD & 12 \\
6 & $\mathrm{GT} / 4$ & Fisch ITF-A & NED with unchanged HB $3 / 6$ & 7 \\
7 & $\mathrm{GJ} / \mathrm{C} 1$ & Fisch ITF-A & stable with residual disease & 1.5 \\
8 & $\mathrm{GJ} / \mathrm{C} 3$ & Fisch ITF-A & RTD for recurrence/NED & 9 \\
\hline
\end{tabular}

CBT - carotid body tumour, GT - glomus tympanicum, GJ - glomus jugulare, NED - no evidence of disease, RTD - radiotherapy, SWD - stable with disease, HB - House-Brackmann grade, ITF-A - Infratemporal Fossa Approach Type A. 


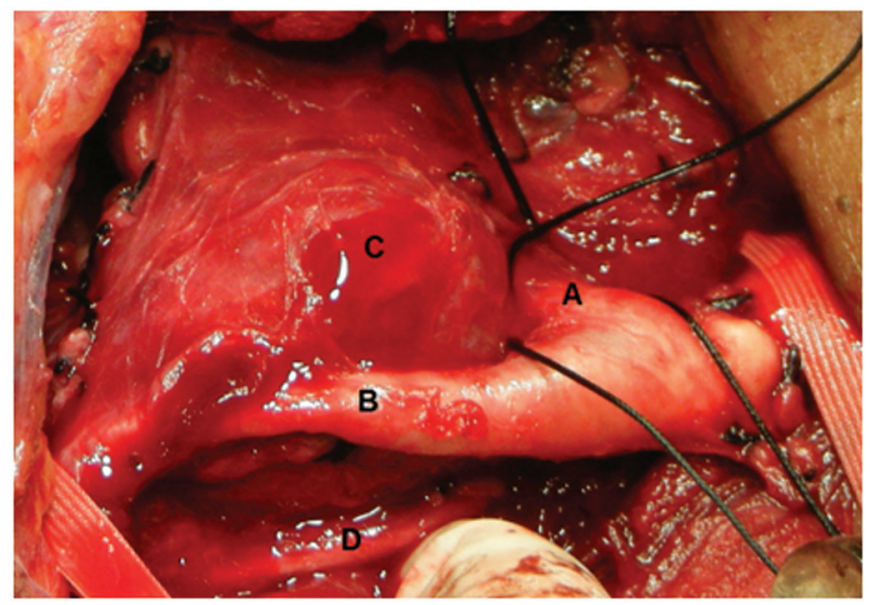

Figure: An intraoperative view of surgical excision of a carotid body tumour.

A: external carotid artery, B: internal carotid artery, C: carotid body tumour, D: vagus nerve.

with a dehiscent tympanic facial nerve segment. One patient (Case 5) had surgery in 2004 and developed local recurrence eight years post-surgery. This patient was awaiting repeat treatment and was stable with disease. This patient also had a preoperative HouseBrackmann grade (HB) 6/6 which remained unchanged postoperatively. Another patient (Case 6) had a Fisch Infratemporal Fossa Approach Type A (ITF-A approach) and was disease-free seven years postoperatively. However, the preoperative facial nerve palsy (HB 3/6) remained unchanged postoperatively. Additionally, two patients with GJ tumours had Fisch ITF-A approaches. One of these patients (Case 8) who had Fisch C3 disease with $\mathrm{CN}$ 9-12 palsies developed local recurrence two years after surgery. This was treated with adjuvant radiotherapy. This patient was disease-free four years post-radiation therapy. However, lower $\mathrm{CN}$ palsies still persisted with minimal symptoms. The other patient (Case 7) had residual disease medial to the mastoid facial nerve segment. Seven patients were awaiting definitive treatment (Table 3). One patient (Case 14) was referred overseas due to extensive disease that would require specialized modalities not available locally. One patient (Case 15) with GV with internal carotid artery (ICA) encasement and extensive disease defaulted.

\section{DISCUSSION}

In the reported literature, CBTs are the most common HNPGs, accounting for $63-78 \%$ of the cases in most series, followed by GJ, GT and GV tumours (7). This contrasts with this current series in which GT tumours accounted for $53 \%$ of the cases, followed by GJ (27\%),
CBTs (13\%) and GV (7\%). This finding could be attributed to the small, non-representative sample of this series, selection bias and possibly a unique characteristic of this population. The latter can be ascertained with a larger sample size. The overall demographics with a female preponderance and age presentation between the fourth and sixth decades were consistent with other international reported series (7-9).

Temporal PGs often present at advanced stages due to their slow growth and associated paucity of symptoms. However, with a high clinical acumen, their early detection can be made based on certain clinical features. These include the two most common symptoms of pulsatile tinnitus and hearing loss seen in $80-98 \%$ and $60-63 \%$ of the patients respectively (10), congruent with our findings. The most common clinical finding of a temporal PG is a vascular middle ear mass (11) which was evident in all patients with GT tumours. Additionally, GJ tumours can present as a vascular mass when it erodes into the floor of the hypotympanum and as an aural polyp when eroded through the tympanic membrane or external auditory canal. This sign was evident in $50 \%$ of the patients with GJ in our series. Additionally, GJ often presents with cranial neuropathies in $37 \%$ of the cases, due to their involvement of the surrounding neurovascular structures (1). Furthermore, tumour extension through the facial recess and retrofacial air cells may result in facial nerve involvement in $21-33 \%(11,12)$. The constellation of the above symptoms and signs should raise suspicion of a temporal PG and warrant referral to the ENT Service. Uncommon signs such as Brown sign (tumour blanching with positive pressure using pneumatoscopy) seen in 10-30\% (11) or Aquino sign (cessation of pulsations with compression of the ipsilateral carotid artery) may be evident (11).

A carotid body tumour usually presents as a slowgrowing, asymptomatic lateral neck mass, which demonstrates craniocaudal immobility because of its

Table 3: Patients awaiting definitive treatment

\begin{tabular}{llll}
\hline Case & Age/gender & Tumour/stage & Proposed plan \\
\hline 9 & $48 / \mathrm{F}$ & GT/4 & Surgery \\
10 & $71 / \mathrm{F}$ & GT/4 & Surgery \\
11 & $53 / \mathrm{F}$ & GT/4 & Surgery \\
12 & $48 / \mathrm{F}$ & GT/3 & Surgery \\
13 & $49 / \mathrm{F}$ & GJ/C1 & Surgery \\
14 & $13 / \mathrm{F}$ & GJ/De2 & Referred overseas \\
15 & $59 / \mathrm{M}$ & GV & Defaulted \\
\hline
\end{tabular}

GT - glomus tympanicum, GJ - glomus jugulare, GV - glomus vagale. 
adherence to the carotid arteries, the positive Fontaine sign $(13,14)$. This was evident in $100 \%$ of all the patients with CBTs in our series. Most GV tumours present as an asymptomatic neck mass, as in our lone case, or with larger lesions, compressive symptoms and cranial neuropathies such as vagus nerve palsy in $50 \%$ of the cases (15).

Multicentricity occurs in 10-20\% and $80 \%$ of sporadic and hereditary cases, respectively (16). Furthermore, HNPGs are functional in 2-4\% of cases (5). Additionally, malignant PGs defined by the presence of pathologically metastatic spread to lymph nodes or distant organs, rather than by the histological features of the primary tumour, can occur in $4-15 \%$ of cases (17). These were not evident in our series.

Surgery is the treatment modality frequently employed, depending on a number of factors (patient, disease, surgeon, institution). Non-surgical methods, observation and radiation are often palliative in advanced or recurrent cases. The surgical approach depends on the tumour stage. Head and neck paragangliomas limited to the tympanic cavity and tympanomastoid area (Fisch A and B tumours/Types I-IV) are addressed by standard otological techniques using endaural or postauricular exposure with excellent success and minimal morbidity. These techniques include transcanal and transmastoid (with or without extended facial recess) approaches. Our institutions' surgical outcomes were congruent with the reported literature $(7,8)$. For larger tumours, classes $\mathrm{C}$ and D, the Fisch ITF approaches are the gold standard methods (3). Sanna et al (18) and Makiese et al (19) reported on their experience of GJ lesions (Fisch Class C/D) which demonstrated local control rates of 78.7$83 \%$, HB I/II postoperative rates of $65.8-93.7 \%, 5.3 \%$ incidence of postoperative leak of cerebrospinal fluid, $25 \%$ incidence of lower cranial neuropathies, and $2.7 \%$ operative mortality. In our series, the surgical outcomes of two patients with GJ Fisch C disease who had Fisch ITF-A approaches mirrored those of the larger centres $(18,19)$, despite our limitations.

Carotid body tumours are managed surgically unless a medical contraindication or patient's preference exists (20). All our patients had transcervical resection with no sequelae, which is consistent with the reported literature $(14,21)$.

The optimal treatment of patients with GV requires an individualized approach. However, surgical excision remains the treatment of choice (22). The patient with GV had an extensive disease involving his ICA which surgically is associated with significant morbidity and mortality. Ideally, Balloon test occlusion (BTO) and preoperative embolization could assist in the patient's management. However, the patient defaulted from follow-up.

Conventional fractionated external beam radiotherapy has been used as the primary treatment in patients for whom surgery is contraindicated (23). Additionally, it can be used adjuvantly as salvage treatment for residual disease (23), as was done in Case 8. Stereotactic radiosurgery/radiotherapy (SRS/SRT) is another option that has been employed in suitable patients with tumour control rates of $>90 \%$ (24). Unfortunately, locally, SRS/ SRT is not available.

This retrospective analysis has the inherent weaknesses and limitations associated with a retrospective analytical methodology. These included selection and surgeon biases, poor recording, no standard treatment regimes, small sample size and limited resources.

\section{CONCLUSION}

In contrast to the reported international literature, the most common HNPG in this series was GT. This could be related to the small sample size or could be a finding unique to this population. The latter will be explored in further studies. The clinicopathological, radiological and treatment outcomes were similar to those in the reported literature, despite the inherent limitations in Jamaica. Notwithstanding these limitations, this study can be used as a substratum to facilitate early recognition and successful management of HNPGs.

\section{REFERENCES}

1. Miller JP, Semaan MT, Maciunas RJ, Einstein DB, Megerian CA. Radiosurgery for glomus jugulare tumors. Otolaryngol Clin North Am 2009; 42: 689-706.

2. Destito D, Bucolo S, Florio A, Quattrocchi C. Management of head and neck paragangliomas: a series of 9 cases and review of the literature. Ear Nose Throat J 2012; 91: 366-75.

3. Gjuric M, Gleeson M. Consensus statement and guidelines on the management of paragangliomas of the head and neck. Skull Base 2009; 19: 109-16.

4. Shamblin WR, ReMine WH, Sheps SG, Harrison EG, Jr. Carotid body tumor (chemodectoma). Clinicopathologic analysis of ninety cases. Am J Surg 1971; 122: 732-9.

5. Jackson CG, Glasscock ME, $3^{\text {rd }}$, Harris PF. Glomus tumors. Diagnosis, classification, and management of large lesions. Arch Otolaryngol 1982; 108: 401-10.

6. Browne JD, Fisch U, Valavanis A. Surgical therapy of glomus vagale tumors. Skull Base Surg 1993; 3: 182-92.

7. Erickson D, Kudva YC, Ebersold MJ, Thompson GB, Grant CS, van Heerden JA et al. Benign paragangliomas: clinical presentation and treatment outcomes in 236 patients. J Clin Endocrinol Metab 2001; 86: 5210-6.

8. Neskey DM, Hatoum G, Modh R, Civantos F, Telischi FF, Angeli SI et al. Outcomes after surgical resection of head and neck paragangliomas: a review of 61 patients. Skull Base 2011; 21: 171-6. 
9. Prasad SC, Thada N, Pallavi, Prasad KC. Paragangliomas of the head \& neck: the KMC experience. Indian J Otolaryngol Head Neck Surg 2011; 63: 62-73.

10. Green JD, Jr, Brackmann DE, Nguyen CD, Arriaga MA, Telischi FF, De la Cruz A. Surgical management of previously untreated glomus jugulare tumors. Laryngoscope 1994; 104: 917-21.

11. Jackson CG. Glomus tympanicum and glomus jugulare tumors. Otolaryngologic Clinics of North America 2001; 34: 941-70.

12. Spector GJ, Gado M, Ciralsky R, Ogura JH, Maisel RH. Neurologic implications of glomus tumors in the head and neck. Laryngoscope 1975; 85: 1387-95.

13. Wang SJ, Wang MB, Barauskas TM, Calcaterra TC. Surgical management of carotid body tumors. Otolaryngol Head Neck Surg 2000; 123: 202-6.

14. van der Mey AG, Jansen JC, van Baalen JM. Management of carotid body tumors. Otolaryngol Clin North Am 2001; 34: 907-24, vi.

15. Weissman JL. Case 21: glomus vagale tumor. Radiology 2000; 215: $237-42$.

16. Jackson CG. Glomus tympanicum and glomus jugulare tumors. Otolaryngol Clin North Am 2001; 34: 941-70, vii.

17. Moskovic DJ, Smolarz JR, Stanley D, Jimenez C, Williams MD, Hanna EY et al. Malignant head and neck paragangliomas: is there an optimal treatment strategy? Head Neck Oncol 2010; 2: 23.
18. Sanna M, Jain Y, De Donato G, Rohit, Lauda L, Taibah A. Management of jugular paragangliomas: the Gruppo Otologico experience. Otol Neurotol 2004; 25: 797-804.

19. Makiese O, Chibbaro S, Marsella M, Tran Ba Huy P, George B. Jugular foramen paragangliomas: management, outcome and avoidance of complications in a series of 75 cases. Neurosurg Rev 2012; 35: 185-94.

20. Amato B, Bianco T, Compagna R, Siano M, Esposito G, Buffone G et al. Surgical resection of carotid body paragangliomas: 10 years of experience. Am J Surg 2014; 207: 293-8.

21. Lim JY, Kim J, Kim SH, Lee S, Lim YC, Kim JW et al. Surgical treatment of carotid body paragangliomas: outcomes and complications according to the Shamblin classification. Clin Exp Otorhinolaryngol 2010; 3: 91-5.

22. Sniezek JC, Netterville JL, Sabri AN. Vagal paragangliomas. Otolaryngol Clin North Am 2001; 34: 925-39.

23. Krych AJ, Foote RL, Brown PD, Garces YI, Link MJ. Long-term results of irradiation for paraganglioma. Int J Radiat Oncol Biol Phys 2006; 65: $1063-6$.

24. Suarez C, Rodrigo JP, Bodeker CC, Llorente JL, Silver CE, Jansen JC et al. Jugular and vagal paragangliomas: systematic study of management with surgery and radiotherapy. Head Neck 2013; 35: 1195-204. 